\title{
Characteristics in milk influencing the cheese yield and cheese quality
}

\author{
S. Skeie ${ }^{1}$ \\ Department of Chemistry, Biotechnology and Food Science, \\ Norwegian University of Life Sciences \\ P.O. Box 5003, N-1432 As, Norway
}

\begin{abstract}
This review will give a short introduction to the principles of cheesemaking and some definitions of cheese yield, and the characteristics in milk influencing the cheese yield and cheese quality will be discussed. Good quality milk, giving an optimal cheese yield and cheese quality, originate from healthy animals, has good flavour, has been cold stored for a limited amount of time and has a high protein content with the BB genotypes of $\beta$-lactoglobuline and $\kappa$-casein (bovine milk). The milk should be low in somatic cell count, as proteases from somatic cells attacks $\alpha_{\mathrm{S} 2}$ - and $\beta$ caseins and reduce the cheese yield. The content of free fatty acids should be low, as free fatty acids bind $\mathrm{Ca}^{2+}$ and thereby reduce the coagulation properties of the milk, in addition free fatty acids contribute to the development of rancid flavour in cheese. Milk used for cheesemaking must be of good microbiological quality, pathogenic bacteria should be absent, psychotropic bacteria have heat resistant lipases and proteases which may reduce yield, but may also cause undesirable flavours in the ripened cheese. Clostridia spores cause late blowing in cheeses with eyes, but also to cheeses with closed texture these bacteria induce inedible flavours. Antimicrobial agents as antibiotics, detergents etc. must be absent, as the acidification by lactic acid bacteria will be strongly influenced.
\end{abstract}

KEY WORDS: milk quality, cheese yield, cheese quality

\section{INTRODUCTION TO THE PRINCIPLES OF CHEESEMAKING}

What is a cheese?

Codex alimentarius (2003) has set a standard for cheese:

Cheese is the ripened or unripened soft or semi-hard and extra hard product, which may be coated, and in which the whey protein/casein ratio does not exceed that of milk, obtained by:

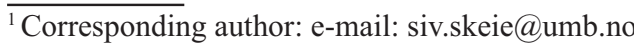


a. coagulating wholly or partly the protein of milk, skimmed milk, partly skimmed milk, cream, whey cream or buttermilk, or any combination of these materials, through the action of rennet or other suitable coagulating agents, and by partially draining the whey resulting from such coagulation; and/or

b. processing techniques involving coagulation of the protein of milk and/ or products obtained from milk which give an end-product with similar physical, chemical and organoleptic characteristics as the product defined under a. refers to traditional cheesemaking, while b. refers to the use of novel techniques as e.g., ultrafiltration for cheesemaking.

\section{Casein}

Protein constitutes $95 \%$ of the nitrogen containing compounds in milk, while the remaining 5\% is non protein nitrogen (NPN). Eighty percent of the protein is casein, which we utilize when making cheese. Most of the whey proteins which constitute about $20 \%$ of the proteins will be lost with the whey during cheesemaking. The molecular components in casein are $\alpha_{\mathrm{S} 1}, \alpha_{\mathrm{S} 2}, \beta$ and $\kappa$-casein differing in amino acid composition, phosphorylation and glycosylation. However, these molecules are polymorphic with several genetic variants. These four caseins are organized in casein micelles, where the hydrophobic caseins $\left(\alpha_{\mathrm{S} 1}, \alpha_{\mathrm{S} 2}\right.$ and $\left.\beta\right)$ are situated in the core, while the more hydrophilic $\kappa$-casein is situated on the surface. $\kappa$-casein contains carbohydrate groups, which make parts of this casein hydrophilic resulting in a negative net charge. This $\mathrm{C}$ terminal hydrophobic part of $\kappa$-casein stand out from the surface of the micelle, stabilizing it from clotting with other casein micelles and precipitate from the milk serum. Nanoclusters of calcium phosphates bind the casein molecules through esterification to serine (Ser) residues at the casein molecules. The salts in milk are in a dynamic equilibrium, with the colloidal calcium phosphate (CCP) situated within the micelles and $\mathrm{Ca}^{2+}$ and $\mathrm{H}\left(\mathrm{PO}_{4}\right)^{2-}$ in the milk serum (Walstra et al., 2006). In the milk serum, an equilibrium exist also among the phosphates $\mathrm{H}\left(\mathrm{PO}_{4}\right)^{2-}$ and $\mathrm{H}_{2}\left(\mathrm{PO}_{4}\right)^{-}$as shown in Figure 1.

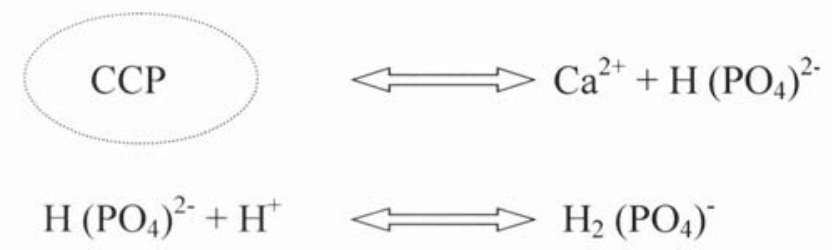

Figure 1. Equilibrium of calcium and phosphates in milk 


\section{Coagulation of milk}

Renneting of milk can be divided in three phases: 1. the enzymatic phase; 2. the coagulation and gel formation phase; 3 . the syneresis and contraction phase. In the first phase, rennet act upon the 105-106 phenylalanine (phe)methionine (met) bonding at the $\kappa$-casein. By this action, $\kappa$-casein looses its hydrophilic residue (glycomacropeptide) and gradually the casein micelle looses its stabilizing element. In order to recover stability, the casein micelles starts to aggregate, provided that $\mathrm{Ca}^{2+}$ is accessible. Gradually, as more and more of the glycomacropeptide is removed from the casein micelles, strands of micelles are formed and clotting can be observed as flocculation in the milk: the coagulation and gel formation phase has started. During this phase, a network of casein micelles is made, incorporating whey, bacteria and fat globules. The network is irregular and the pores allow flow of liquid in the matrix. As the entire surface of the casein micelles have become open with reactive sites, reorganization of the network starts and the gel contracts i.e. the third phase, syneresis starts. When the gel is cut, the reorganization and contraction of the curd particles accelerate, as the framework is cut to pieces and a new framework within each curd particle has to be made. This results in separation of whey from the curd and hardening of the curd particles (Dejmek and Walstra, 2004; Fox et al., 2004; Horne and Banks, 2004; Walstra et al., 2006).

A flowsheet of a manufacturing protocol for a Gouda type cheese is shown in Figure 2. During cheesemaking the added starter bacteria ferment lactose to lactic acid and $\mathrm{pH}$ is reduced. By this operation, the renneting and syneresis properties of the milk coagulum is improved. The $\mathrm{pH}$ drop also causes leakage of CCP from the casein micelles to the milk serum, as the production of $\mathrm{H}^{+}$disturbs the calcium phosphate equilibrium. This leads to a more open structure of the casein micelles, as the bindings between the casein molecules are weakened and the rennet enzymes can start their action on the other caseins, especially $\alpha_{\mathrm{S} 1}$-casein. Degradation of $\alpha_{\mathrm{S} 1}$-casein by rennet during the first two weeks of ripening modifies the structure of the cheese; it obtains a less rubbery and more smooth structure (Lawrence et al., 1987). However, the most important proteolytic action for the later cheese ripening, where the desired texture and flavour is developed, comes from milk plasmin and bacterial enzymes. The protein content and protein polymorphism of the milk influence the above described process and in the end influences the cheese yield and the economy of cheese production. 


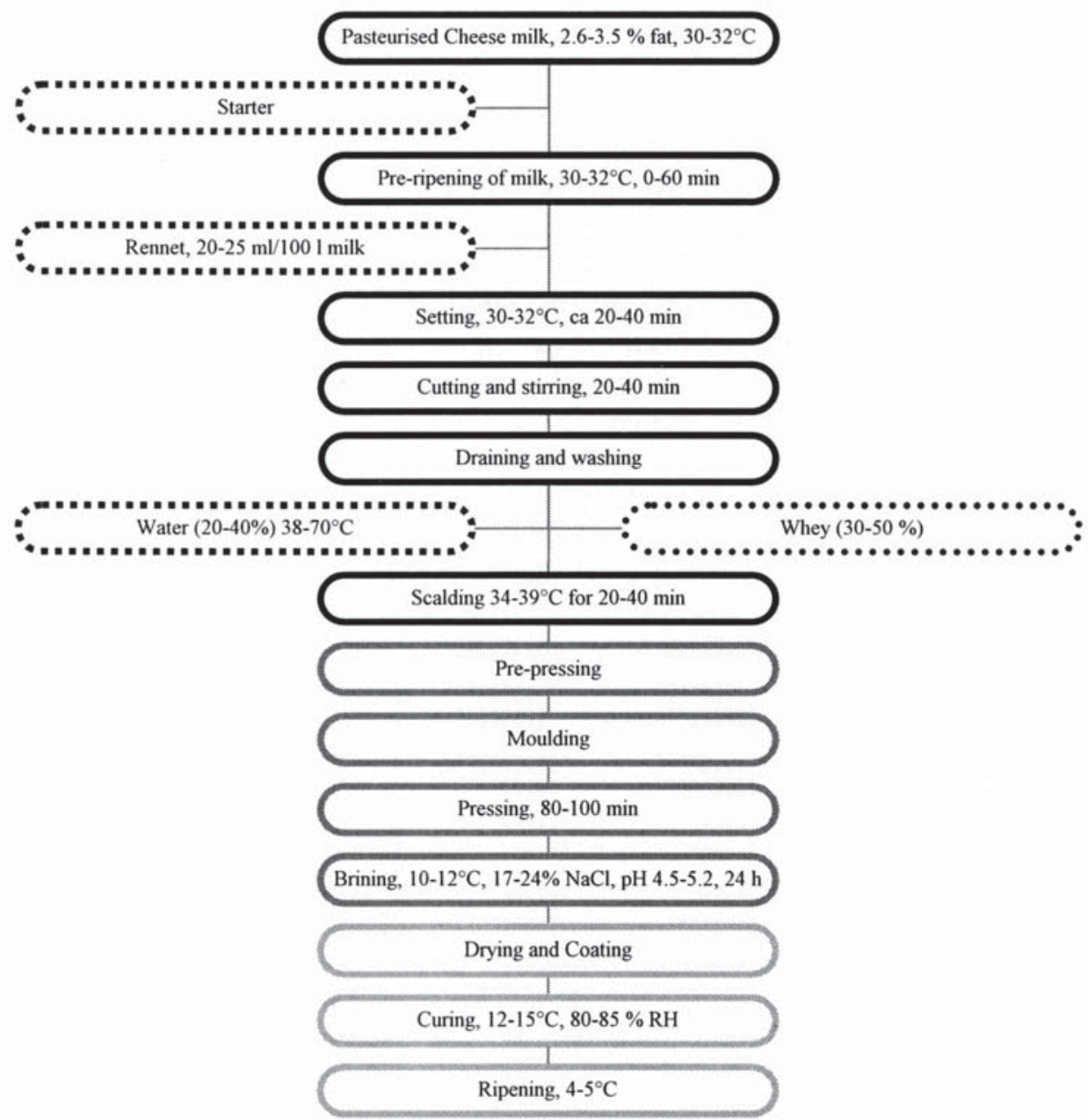

Figure 2. Transformation of milk to cheese; flowsheet of the cheesemaking process for a Gouda type cheese

\section{DEFINITIONS OF CHEESE YIELD}

Cheese yield is defined as the amount of cheese $(\mathrm{kg})$ obtained per $100 \mathrm{~kg}$ of milk for a certain cheese variety. However, many dairies define it according to how many litres of milk which is necessary to produce 1000 tonnes of cheese (Lucey and Kelly, 1994). Van den Berg et al. (1996) calculated the transfer of protein from milk to cheese; starting with $100 \mathrm{~kg}$ of paracasein (including 
adsorbed peptides and fat globule membrane proteins) from milk and starter, $100.9 \mathrm{~kg}$ of protein could be found in the cheese. This increase was due to several factors: 1 . increase in the protein content due to pasteurization and bactofugation (strictly, due to UHT treatment of the bactofugate) where a small amount of the whey protein $\beta$-lactoglobuline $(\mathrm{lg})$ attracts to the $\kappa$-casein of the casein micelle; 2 . some whey proteins will be left in the cheese structure as the cheese moisture is whey; 3 . the peptides formed during hydrolysis of $\alpha_{\mathrm{S} 1}$-casein by rennet increases water binding. However, it is also a loss of protein during cheesemaking due to loss of cheese fines, i.e. cheese particles so small that they can escape with the whey, and due to loss of proteins and CCP during brining. Several attempts have been made to develop formulas to predict cheese yield for various cheese varieties, these have been discussed and reviewed by Emmons et al. (1990) and Lucey and Kelly (1994). Although cheese yield formulas have some limitations, they are useful to understand the influence of the different factors influencing cheese yield. The most used formula was developed for Cheddar by Van Slyke 100 years ago based on a two year study on 48 cheddar factories around New York.

$$
\frac{(0.93 F+C-0.1) \times 1.09}{100-W} \times 100
$$

F - fat in milk, \%

C - casein in milk, \%

$\mathrm{W}$ - water content of cheese, $\%$

0.1 - constant for loss of cheese fines

1.09 - constant representing the retention of soluble salts, lactose and salt addition (Van Slyke, 1894)

As the fat content of the cheese usually is standardized, the protein content seems to be the most important factor for cheese yield. However, today many cheese plants also do protein standardization, and the variation in cheese yield is minimized at these cheese plants. However, some variation in cheese yield is still observed, and other factors which are not described in the cheese yield formulas need to be considered.

\section{FACTORS IN MILK INFLUENCING CHEESE YIELD}

\section{Protein content and genetic variants of protein}

As can be seen from the cheese yield formula (1), cheese yield increase with increasing protein content, but this is not always the case. The protein content has 
been an important factor in breeding programs of dairy breeds and for the payment systems of the farmers. During the last 30 years, it has been an enormous increase in milk yield per cow. However, according to Lindmark-Mansson et al. (2003) the protein content of Swedish milk remained constant during a period from 1970 until 1996, but the amount of casein was reduced and the amount of whey proteins were increased. This might be explained by the prevalence of $\beta$-lactoglobuline (Lg) A (Lindmark-Mansson et al., 2003) which has been shown to be associated with a higher protein content and a higher milk yield (Klantschitsch et al., 2000). Different breeds differs in their protein and fat content, Jersey milk has higher protein and fat content than Friesian milk and has therefore better cheesemaking properties (Auldist et al., 2004). Auldist et al. (2004) showed that this was entirely related to the total solid composition of the milk, and had no connection to the genotype of $\kappa$-casein. It is a general conclusion from several studies, that milk with the best cheesemaking abilities is obtained with the BB variant of $\beta-\lg$ and $\kappa$-casein (van den Berg et al., 1996; Walsh et al., 1998). Milk with the BB variant of $\beta$ - Lg has a higher casein to total protein ratio, and a higher casein content. Milk with the BB variant of $\kappa$-casein is associated with a higher casein level and higher $\kappa$-casein content, resulting in smaller micelles, which give shorter rennet coagulation time and higher curd firmness.

Mayer et al. (1997) showed, however, that the composite milk protein phenotype effect were also of importance for the cheese yield. Milk with the combination $\beta$-casein $\mathrm{A}^{2} \mathrm{~A}^{2}, \kappa$-casein AA and $\beta$-Lg AA gave 30\% lower cheese yield compared to milk with the $\mathrm{BB}$ variants of $\kappa$-casein and $\beta-\mathrm{Lg}$. However, a higher cheese yield was obtained from milk with $\beta$-casein $\mathrm{A}^{2} \mathrm{~B}, \kappa$-casein $\mathrm{AA}$ and $\beta$-Lg AA than from milk with the combination $\kappa$-casein $B B, \beta-\operatorname{Lg} B B$ and $\beta$-casein $A^{2} B$. Another conclusion from this work was that the perfect combination does not exist, because no combination gave the lowest fat in whey, lowest cheese fines, highest cheese yield and the highest proteolysis.

Wedholm et al. (2006) investigated the milk clotting properties and cheese yield in milk from individual Swedish and Danish cows. They found that milk samples resulting in a weak coagulum had a low concentration of $\kappa$-casein and a low amount of $\kappa$-casein in proportion to total casein. Milk having the AA genotype of $\kappa$-casein had lower concentrations of $\kappa$-casein than milk having the $\mathrm{AB}$ genotype. They also found a high frequency of $\kappa$-casein $\mathrm{AE}$ in milk with poor coagulation properties. Wedholm et al. (2006) conclude that milk for cheesemaking should be selected for high concentrations of $\alpha_{\mathrm{S} 1}, \beta$ and $\kappa$-casein and $\beta$-Lg B.

\section{Leakage of CCP and $\beta$-casein during cold storage}

In the casein micelle, calcium phosphate is supersaturated and in equilibrium with dissociated ions in the milk serum (Figure 1). At low temperatures, as used 
during cold storage of milk, the solubility of $\mathrm{Ca}^{2+}$ in the milk serum increase. Colloidal calcium phosphate (CCP) is therefore drawn from the casein micelles to the serum to recover equilibrium. At first the loosely bound CCP is removed, which does not affect the micelle structure significantly, but when the more strongly bound CCP starts to leave the micelle, the micellar structure opens up, resulting in weakening of the CCP bindings between the casein molecules. $\beta$-casein has few Ser-phosphate groups and is mainly bound to the micelle by hydrophobic bonds, which are weakened at low temperature, and it therefore starts to leak from the micelle at low temperatures (Walstra et al., 2006).

Reimerdes and Klostermayer (1976) observed that the concentration of $\beta$-casein increased from 0.25 to $0.9 \%$ in the milk serum after $2 \mathrm{~h}$ storage at $5^{\circ} \mathrm{C}$. However, they also observed that most of the leakage occurred at the start of the cooling period, as the concentration of $\beta$-casein in the milk serum only increased to $1 \%$ after $20 \mathrm{~h}$ at $5^{\circ} \mathrm{C}$. The leakage of $\mathrm{CCP}$ and $\beta$-casein are reversed at elevated temperatures as pasteurization, therefore, only minor effects can be observed on the renneting properties of milk during cheese production. However the $\beta$-casein may be exposed to proteolytic action from indigenous milk enzymes or proteases produced by psychrotrophic microorganisms, and the proteolysis products will not be recovered to the casein micelles by heating, but will be lost with the whey. Proteolytic action on $\beta$-casein during cold storage will therefore result in reduced cheese yield. It is therefore extremely important that the somatic cell count and the microbial contamination are kept as low as possible in milk used for cheese production.

\section{Somatic cell count}

Milk with a high somatic cell count (SSC) (>500 000 cells per mL milk) reduces cheese yield (Auldist et al., 1996), as this milk is associated with higher proteolytic activity, lower concentration of fat and casein and a higher content of whey proteins especially serum albumin and immunoglobulin. The somatic cells contain a plasmin activator that converts plasminogen to plasmin in the mammary gland (Lucey and Kelly, 1994). According to de Rham and Andrews (1982) plasmin totalled one third of the total protease activity in milk with high SSC. Plasmin degrades mainly $\beta$ and $\alpha_{\mathrm{S} 2}{ }^{-}$ casein into peptides, and this reaction is still active at $5{ }^{\circ} \mathrm{C}$, however with only slight activity (van den Berg et al., 1996). Barbano et al. (1991) suggests that the upper limit for SSC for cheese milk should be 100000 per mL milk. This was based on results showing a marked decrease in cheese yield at SSC $>100000$ per mL milk.

\section{Psychotropic bacteria}

According to Sørhaug and Stepaniak (1991) the total level of bacteria in raw milk is in the range $10^{4}-10^{6} \mathrm{cfu} / \mathrm{mL}$. When the microflora exceeds $10^{4} \mathrm{cfu} / \mathrm{mL}$, the flora is 
dominated by Gram- and lactose ${ }^{-}$psychrotrophic bacteria, while in fresh raw milk with low bacterial counts, a mesophile flora is dominating. In newly drawn milk, 1 to $10 \%$ of the total bacterial count is psychrotrophic bacteria, while these dominate totally after 2 to 3 days of storage. In an experiment on Norwegian and Swedish raw milk (Ternstrom et al., 1993), the psychrotrophic flora totalled $80 \%$ of the microflora when the cfu $/ \mathrm{mL}$ exceeded $10^{7}$. Dominating strains were Pseudomonas $(P$.) with the species $P$. fluorescens biovar 1 and biovar 3, P. fragi and $P$. lundensis. Psychrotrophic bacteria have an average generation time at $4^{\circ} \mathrm{C}$ between 4.5 and $11 \mathrm{~h}$ (Sørhaug and Stepaniak, 1991). According to Suhren (1989) the critical storage time for raw milk is between 60 and $72 \mathrm{~h}$ when the temperature is between 2 and $4^{\circ} \mathrm{C}$. Therefore, thermalization of the milk is often used at arrival, when the dairy plant needs to store the raw milk longer than 2 days. The Gram;, psychrotrophic bacteria do not represent a quality problem as such in milk, and most of these bacteria are killed by pasteurization. However, they produce heat resistant extracellular proteases and lipases which may cause severe problems (Mottar, 1989) as the conditions in milk is very good for their proteolytic enzymes. Kohlmann et al. (1991) found that proteases from P. fluorescens M3/6 had activity on $\alpha-, \beta$ - and $\kappa$-caseins. Frohbieter et al. (2005) showed that proteases produced by P. fluorescens M3/6 stimulated plasminogen activators, resulting in the transformation of plasminogen to plasmin.

\section{Lactation}

The concentration of milk constituents vary during lactation (Lucey and Kelly, 1994). Colostrum milk has a high content of fat and protein. From around week 5, the fat and protein content is at its minimum with a steady increase during lactation. The concentration of lactose on the other hand, decreases slowly during lactation (Fox et al., 2000). Guinee et al. (2007) showed that the protein content of the milk increased during lactation and that the cheese yield increased similarly to the protein content. At very late lactation the protein content and the cheese yield dropped, however, when the yield were normalized per $100 \mathrm{~kg}$ of milk with reference levels of fat and protein, the yield did not decrease to the same extent during very late lactation. Several authors (Kefford et al., 1995; Auldist et al., 1996; Guinee et al., 2007) stress the importance of balancing the diet with the lactation. Very late lactation milk has been known to have inferior properties for cheese making; however this may be avoided by balancing the diet. In late lactation milk, the numbers of SSC increase, the content of whey protein increase on the expense on casein, however if the cows were offered a high quality diet this did not occur (Kefford et al., 1995). Late lactation milk with high counts of SSC has poor coagulation abilities, resulting in a weak curd with poor syneresis of the casein network and therefore a cheese with higher moisture content is obtained 
(Auldist et al., 1996). This could be attributed to more serum proteins in the milk, giving hydrophilic properties and a higher milk $\mathrm{pH}$. The level of plasmin, plasminogen and plasminogen activator increase in milk during lactation (Baldi et al., 1996), and plasminogen peaked during the fifth month of lactation, while the ratio of plasminogen to plasmin decreased during lactation, this indicate increased conversion of plasminogen to plasmin during lactation.

\section{Seasonal variation}

In regions with changing climate or where milk production has a seasonal pattern, large seasonal variation can be found on milk composition. When milk production has a seasonal pattern, these changes can partly be attributed to lactation. In Australia, New Zealand and Ireland it is a very clear seasonal pattern due to lactation (Kefford et al., 1995). However, the quality of feed may be more important than the stage of lactation for the cheesemaking properties of the milk (Kefford et al., 1995). Van den Berg (1996) refers that calcium, magnesium, inorganic phosphate and citrate show a similar seasonal trend in Dutch milk, and that the ratio of colloidal minerals and citrate was highest in March/April and lowest in August. In Norway and Sweden it is a very clear seasonal pattern due to climate, although some geographical areas also have a seasonal pattern due to concentrated calving. Lindmark-Mansson et al. (2003) found seasonal variation in most of the 94 analysed parameters, which was correlated to outdoor grazing from May till October. In Norway, Johansen et al. (2002) found that the amount of proteins in whey was at its highest during summer and winter time with a drop during spring and autumn, while the content of urea (non protein nitrogen) was lower during summer time.

\section{The content of free fatty acids}

Free fatty acids bind $\mathrm{Ca}^{2+}$ and thereby reduce the coagulation properties of milk (Jenkins, 1984). Especially the presence of free fatty acids with a chain length between 8 and 12 carbons are critical. When the amount of free capric (C:10) or lauric (C12) acid was 4000 ppm the milk did not clot at all (Jenkins, 1984). Normally the amount of free fatty acids is low in milk as the milk fat is protected from lipolysis by the fat globule membrane. However, the fat globule membrane may be destroyed by severe mechanical treatment, and the triacylglycerides may be hydrolysed by bacterial and indigenous lipases. Bacterial lipases may also hydrolyse triacylglycerides in intact fat globules, of which the indigenous lipases cannot (Mottar, 1989). The presence of free fatty acids also contributes to the development of rancid flavour in cheese. Hickey et al. (2006) found a significant difference in free fatty acids with lactation, with the lowest content in cheese from 
early lactation milk ( $\sim 90$ days) and the highest in late lactation milk ( $\sim 250$ days). The esterase activity in the cheeses during ripening was also highest in the late lactation milk. These differences were explained by differences in the non starter lactic acid bacteria (NSLAB) population.

\section{CHARACTERISTICS IN MILK INFLUENCING THE CHEESE QUALITY}

When producing cheese not only cheese yield is of importance, but also cheese quality. It is of no benefit if the cheese yield is high if the cheese quality is poor and unattractive to the consumers. What is a good cheese milk taking both yield and cheese quality into consideration? The milk should have good cheesemaking properties, being a good medium for the lactic acid bacteria to acidify the milk in addition to having good renneting properties. One important factor here is the absence of antimicrobial substances as antibiotics, detergents and the like, as the acidification by lactic acid bacteria will be strongly retarded by such substances. The milk should also be a good substrate for the ripening process.

\section{Microbial quality}

In a ripening aspect, presence of non starter lactic acid bacteria (NSLAB) is of importance. Some NSLAB survive pasteurization, and may influence the ripening process. Mesophile lactobacilli are the main species of NSLAB in cheese; they seem to be of importance for the amino acid metabolism, which derives flavour compounds during cheese ripening. Skeie and Ardö (2000) showed that the amino acid metabolism differed between cheeses made from raw, microfiltered and pasteurized milk, meaning that the microflora of the cheese influenced the cheese ripening process significantly. Østlie et al. $(2004,2005)$ showed that the flora of NSLAB varied between dairies both in Norway and Sweden. This variation must therefore be attributed either to the dairy plant or to the milk from the supply regions.

Milk used for cheesemaking must be of good microbiological quality, with low total count and a low count of psychrotrophic bacteria of which heat resistant proteases and lipases may reduce yield and cause undesirable flavours in the ripened cheese. Pathogenic bacteria should be absent; this is of uppermost importance when cheese is produced from unpasteurized milk. In milk for raw milk cheeses the presence of Staphylococcus (Staph.) aureus should be focused, as this bacterium usually is present in milk from animals with subclinical mastitis, and it has been shown to survive in semi hard cheese during ripening (Spahr and Url, 1994; Bachmann and Spahr, 1995). Staph. aureus produces heat stable enterotoxins with a short onset ( 2 to $6 \mathrm{~h}$ ) which cause nausea, vomiting and 
diarrhoea (Jørgensen et al., 2005). Jørgensen et al. (2005) found that 10 out of 11 cows on a Norwegian farm were carriers of Staph. aureus, however Staph. aureus was also found on the farmer, on equipment in the environment and on the raw milk cheese produced on the farm.

Clostridium tyrobutyricum is an anaerobic sporeforming bacterium which produces butyric acid, $\mathrm{CO}_{2}$ and $\mathrm{H}_{2}$ from lactic acid. In cheeses with eyes ( $\mathrm{pH}$ $>5.3$ ), it causes late blowing on the hot ripening room. But also to cheeses with closed texture $(\mathrm{pH}<5.2)$ these bacteria produce inedible flavours. Of uttermost importance to avoid the presence of these bacteria is "clean silage" without spores, sanitary condition in the cowshed and good hygienic condition during milking (Walstra et al., 2006).

\section{Fatty acid composition of milk}

Feeding strategies in order to change the fatty acid composition of the milk has been focused the recent years within milk production research. Cheese has been made from milk with altered milk fat composition in favour of long chain unsaturated fatty acids, and no influence on cheese quality was found (Lightfield et al., 1993; Allred et al., 2006). However, Jaros et al. (2001) obtained cheese with reduced firmness when using such milk, which is an interesting aspect when dealing with low fat cheese. When making cheese from milk produced by cows fed red-clover (Steinshamn et al., 2006), a higher amount of long chain unsaturated fatty acids were obtained and the texture of a fat reduced cheese was improved (Svanborg, 2006).

\section{CONCLUSIONS - WHAT GIVES GOOD MILK?}

Milk used for cheesemaking should be produced by healthy animals with low somatic cell count, preferably $<100000 / \mathrm{mL}$ milk; the cows should be feed a high quality diet. The milk should have high protein content with the BB variant of $\beta$-lactoglobuline and $\kappa$-casein. The milk should be fresh, meaning that the bulk tank storage time should be as short as possible. If storage is necessary, the milk should be thermalized as early as possible. The milk should have a low content of microorganisms, preferably $<10^{4} \mathrm{cfu} / \mathrm{mL}$ milk, the leakage of calciumphosphate from the micelles should be low (which is nearly impossible if the milk is to be cooled) and low degradation of the precipitated $\beta$-casein. The milk should have good flavour, with no off flavours. Pathogens and clostridia should be absent, but good lactic acid bacteria may be present. The milk should contain no antimicrobial agents. 


\section{REFERENCES}

Allred S.L., Dhiman T.R., Brennand C.P., Khanal R.C., McMahon D.J., Luchini N.D., 2006. Milk and cheese from cows fed calcium salts of palm and fish oil alone or in combination with soybean products. J. Dairy Sci. 89, 234-248

Auldist M.J., Coats S., Sutherland B.J., Mayes J.J., McDowell G.H., 1996. Effects of somatic cell count and stage of lactation on raw milk composition and the yield and quality of Cheddar cheese. J. Dairy Res. 63, 269-280

Auldist M.J., Johnston K.A., White N.J., Fitzsimons W.P., Boland M.J., 2004. A comparison of the composition, coagulation characteristics and cheesemaking capacity of milk from Friesian and Jersey dairy cows. J. Dairy Res. 71, 51-57

Bachmann H.P., Spahr U., 1995. The fate of potentially pathogenic bacteria in Swiss hard and semihard cheeses made from raw-milk. J. Dairy Sci. 78, 476-483

Baldi A., Savoini G., Cheli F., Fantuz F., Senatore E., Bertocchi L., Politis I., 1996. Changes in plasmin-plasminogen-plasminogen activator system in milk from Italian Friesian herds. Int. Dairy J. 6, 1045-1053

Barbano D.M., Rasmussen R.R., Lynch J.M., 1991. Influence of milk somatic-cell count and milk age on cheese yield. J. Dairy Sci. 74, 369-388

Codex, 2003. Codex General Standard for Cheese, A-6-1978, Rev.1-1999. No. Codex Standard A6-1978. FAO/WHO Food Standards

Dejmek P., Walstra P., 2004. The syneresis of rennet-coagulated curd. In: P.F. Fox, P. McSweeney, T. Cogan, T. Guinee (Editors). Cheese: Chemistry, Physics, and Microbiology. Vol. 1. General Aspects. Elsevier, London, No. 1, pp. 71-104

de Rham O., Andrews A.T., 1982. Qualitative and quantitative determination of proteolysis in mastitic milks. J. Dairy Res. 49, 587-596

Emmons D.B., Ernstrom C.A., Lacroix C., Verret P., 1990. Predictive formulas for yield of cheese from composition of milk: A review. J. Dairy Sci. 73, 1365-1394

Fox P.F., Guinee T.P., Cogan T.M., McSweeney P.L.H., 2000. Fundamentals of Cheese Science. Aspen Publication, Gaithersburg, Maryland

Fox P.F., McSweeney P., Cogan T., Guinee T., 2004. Cheese: Chemistry, Physics, and Microbiology. 3rd Edition. Elsevier, London

Frohbieter K.A., Ismail B., Nielsen S.S., Hayes K.D., 2005. Effects of Pseudomonas fluorescens M3/6 bacterial protease on plasmin system and plasminogen activation. J. Dairy Sci. 88, 3392-3401

Guinee T.P., O‘Brien B., Mulholland E.O., 2007. The suitability of milk from a spring-calved dairy herd during the transition from normal to very late lactation for the manufacture of low-moisture Mozzarella cheese. Int. Dairy J. 17, 133-142

Hickey D.K., Kilcawley K.N., Beresford T.P., Sheehan E.M., Wilkinson M.G., 2006. The influence of a seasonal milk supply on the biochemical and sensory properties of Cheddar cheese. Int. Dairy J. 16, 679-690

Horne D.S., Banks J.M., 2004. Rennet-induced coagulation of milk. In: P.F. Fox, P. McSweeney, T. Cogan, T. Guinee (Editors). Cheese: Chemistry, Physics, and Microbiology. Vol. 1. General Aspects. Elsevier, London, No. 1, pp. 47-70

Jaros D., Ginzinger W., Tschager E., Leitgeb R., Rohm H., 2001. Application of oilseed feeding to reduce firmness of hard cheeses produced in the winter feeding period. Int. Dairy J. 11, 611-619

Jenkins K.J., 1984. Distribution of clot-inhibiting free fatty-acids in ultracentrifugal fractions of reconstituted skim milk powder. J. Dairy Sci. 67, 2590-2593

Johansen A.G., Vegarud G.E., Skeie S., 2002. Seasonal and regional variation in the composition of whey from Norwegian cheddar-type and Dutch-type cheeses. Int. Dairy J. 12, 621-629 
Jorgensen H.J., Mork T., Rorvik L.M., 2005. The occurrence of Staphylococcus aureus on a farm with small-scale production of raw milk cheese. J. Dairy Sci. 88, 3810-3817

Kefford B., Christian M.P., Sutherland B.J., Mayes J.J., Grainger C., 1995. Seasonal influences on Cheddar cheese manufacture - influence of diet quality and stage of lactation. J. Dairy Res. 62, 529-537

Klantschitsch T., Bachmann H.P., Puhan Z., 2000. Influence of milk treatment and ripening conditions on quality of Raclette cheese. Lait 80, 51-67

Kohlmann K.L., Nielsen S.S., Ladisch M.R., 1991. Purification and characterization of an extracellular protease produced by pseudomonas-fluorescens M3/6. J. Dairy Sci. 74, 4125-4136

Lawrence R.C., Creamer L.K., Gilles J., 1987. Symposium - Cheese Ripening Technology - Texture Development During Cheese Ripening. J. Dairy Sci. 70, 1748-1760

Lightfield K.D., Baer R.J., Schingoethe D.J., Kasperson K.M., Brouk M.J., 1993. Composition and flavor of milk and Cheddar cheese higher in unsaturated fatty-acids. J. Dairy Sci. 76, 1221-1232

Lindmark-Mansson H., Fonden R., Pettersson H.E., 2003. Composition of Swedish dairy milk. Int. Dairy J. 13, 409-425

Lucey J., Kelly J., 1994. Cheese yield. J. Soc. Dairy Technol. 47, 1-14

Mayer H.K., Ortner M., Tschager E., Ginzinger W., 1997. Composite milk protein phenotypes in relation to composition and cheesemaking properties of milk. Int. Dairy J. 7, 305-310

Mottar J.F., 1989. Effect on the quality of dairy products. In: R.C. McKellar (Editor). Enzymes of Psychrotrophs in Raw Food. CEC Press, Boca Raton, Florida, pp. 228-244

Østlie H.M., Eliassen L., Florvaag A., Skeie S., 2004. Phenotypic and PCR-based characterization of the microflora in Norwegian cheese during ripening. Int. J. Food Microbiol. 94, 287-299

Østlie H.M., Eliassen L., Florvaag A., Skeie S., 2005. Phenotypic and PCR-based characterization of the microflora in Prast cheese during ripening. Int. Dairy J. 15, 911-920

Reimerdes E.H., Klostermeyer H., 1976. Temperaturabhangige Veranderungen in Milch und Milchprodukten. I. Anderungen im Verhaltnis Micelleneiweiss/Serumeiweiss bei der Kuhlung von Milch. Kiel Milchwirt. Forschungsber. 28, 17-25

Skeie S., Ardö Y., 2000. Influence from raw milk flora on cheese ripening studied by different treatments of milk to model cheese. Food Sci. Technol.-Lebensm. Wiss. 33, 499-505

Sørhaug T., Stepaniak L., 1991. Microbial enzymes in the spoilage of milk and dairy products. In: P.F. Fox (Editor). Food Enzymology. Elsevier Applied Science, London, pp. 169-218

Spahr U., Url B., 1994. Behaviour of pathogenic bacteria in cheese - a synopsis of experimental data. Bull. Int. Dairy Federation 298, 2-13

Steinshamn H., Thuen E., Brenøe U.T., 2006. Clover species in grass-clover silages affects milk fatty acid composition. J. Anim. Feed Sci. 16, Suppl. 1, 65-69

Suhren G., 1989. Producer microorganisms. In: R.C. McKellar (Editor). Enzymes of Psychrotrophs in Raw Food. CEC Press, Boca Raton, Florida, pp. 3-34

Svanborg S., 2006. The fatty acid composition of milk and its effect on cheese quality. Master Thesis, Norwegian University of Life Sciences, Ås

Ternstrom A., Lindberg A.M., Molin G., 1993. Classification of the spoilage flora of raw and pasteurized bovine-milk, with special reference to Pseudomonas and Bacillus. J. Appl. Bacteriol. 75, 25-34

van den Berg M.G., van den Berg G., van Boekel M., 1996. Mass transfer processes involved in Gouda cheese manufacture in relation to casein and yield. Neth. Milk Dairy J. 50, 501-540

Van Slyke L.L., 1894. Investigations Relating to the Manufacture of Cheese. New York Agricultural Experimental Station Bulletin

Walsh C.D., Guinee T.P., Reville W.D., Harrington D., Murphy J.J., O‘Kennedy B.T., Fitzgerald R.J., 1998. Influence of kappa-casein genetic variant on rennet gel microstructure, Cheddar cheesemaking properties and casein micelle size. Int. Dairy J. 8, 707-714

Walstra P., Wouters J.T.M., Geurts T.J., 2006. Dairy Science and Technology. 2nd Edition. CRC/ Taylor and Francis, Boca Raton

Wedholm A., Larsen L.B., Lindmark-Mansson H., Karlsson A.H., Andren A., 2006. Effect of protein composition on the cheese-making properties of milk from individual dairy cows. J. Dairy Sci. 89, 3296-3305 